\title{
Enriching educational accountabilities through collaborative public conversations: Conceptual and methodological insights \\ from the Learning Commission approach
}

\author{
Bob Lingard ${ }^{1}$, Aspa Baroutsis ${ }^{2}$, and Sam Sellar ${ }^{3}$ \\ ${ }^{1}$ Institute for Learning Sciences \& Teacher Education, Australian Catholic \\ University, 229 Elizabeth Street, Brisbane, Queensland, 4000, Australia. \\ ${ }^{2}$ Griffith Institute for Educational Research, Griffith University, 176 \\ Messines Ridge Rd, Mount Gravatt, Brisbane, Queensland, 4122, Australia. \\ ${ }^{3}$ Education Studies, Faculty of Education, Manchester Metropolitan \\ University, 53 Bonsall Street, Manchester, M156GX, United Kingdom.
}

This article describes the use of a Learning Commission to experiment with conceptualising and implementing richer modes of educational accountability. A Learning Commission is a form for collaborative thinking that brings different kinds of knowledge and expertise to bear in relation to a common matter of concern: the role of schools in relation to the communities they serve. As part of a broader research project, we used a Learning Commission to coproduce knowledge about community expectations of schools in a regional area of Queensland, Australia. We analysed data generated through this process using a narrative approach and synthesised the findings in a conceptualisation of rich accountabilities that offers an alternative to top-down, test-based modes of accountability. Rich accountabilities raise anew the questions of who should be accountable, what counts and whose practices should be changed by accountability systems. The article thus describes (a) an alternative model of accountability in education and (2) an alternative theorisation of accountability informed by the implementation of this model as a method for co-producing research about schools and communities. The article provides significant conceptual and methodological resources for further experiments in enriching educational accountability.

Keywords: competency group, education accountability, rich accountabilities, Learning Commission, communities, collaboration 


\section{Introduction}

This paper reports on a five-year research project, Pursuing Equity through Rich Accountabilities (PETRA), conducted in regional Queensland, with eight schools (five secondary and three primary). The project ${ }^{1}$ was carried out in collaboration with the Queensland Department of Education and Training (DET). The overarching goal of the project was to contribute to the construction of a richer conception of educational accountability than current, test-based modes that have become prevalent in Australia. To that end, there were five stages and modes of data collection. These included: a regional case study of eight schools; community-based curriculum projects in each of the schools; the constitution of a Learning Commission, based on the model of a 'competency group' (Whatmore 2009; Whatmore \& Landström, 2011), which canvassed broad community views of the purposes and achievements of schools; the use of data gathered through each of these activities to develop rich accounts of school practices and contributions to communities; and the development of a conceptual framework of rich accountabilities.

The study acknowledged that there are two complementary meanings of accountability, namely, being 'held to account' and 'giving an account' (Ranson, 2003). We sought to complexify this binary to develop a richer conception of accountability, including placing greater emphasis on 'giving account' than is the case with extant approaches. The dominant test-based mode in Australia holds schools, principals, and teachers to account in a topdown manner (Lingard and Lewis, 2016), without giving them opportunities to provide accounts of the reasons for their performance, recognising other school achievements, or providing schools and their communities with opportunities to hold the system to account in a bottom-up way (Baroutsis, 2016). In this paper, we focus on the establishment of a Learning Commission, its mode of operation, and its contribution to conceptualising rich, bottom-up modes of accountability in education.

The Learning Commission was modelled on Whatmore's work with colleagues to address issues of significant concern for communities (e.g. flood mitigation) using 'competency groups' (Whatmore, 2009; Whatmore \& Landström, 2011). Competency groups are inspired by democratic imperatives, and as such, constitute 'forums for collaborative thinking' (Whatmore \& Landström, 2011, p. 586) that bring together experts and publics in relation to a problem. Competency groups provide a forum in which thinking about particular problems can be 'slowed down', teased apart and subjected to scrutiny (Whatmore \& Landström, 2011). In the PETRA

\footnotetext{
${ }^{1}$ The PETRA project was funded by the Australian Research Council Linkage scheme (100200841). The research team included Professor Bob Lingard, Professor Peter Renshaw, Professor Martin Mills, Dr Sam Sellar, Dr Aspa Baroutsis, Dr Sue Monk, Dr Richard Waters (The University of Queensland), Professor Marie Brennan, Dr Lew Zipin (Victoria University), Dr John Dungan (Director) and other members of the Strategic Policy and Research Division (Queensland Department of Education, Training and Employment).
} 
project, the problem was the issue of reconceptualising accountability so that it would be of productive use to schools, communities and the education system. The competency group approach recognises that solutions can be found by connecting scientific or research-based expertise with the diverse range of experience and knowledge held by local communities. This approach can be seen to accept that there are useful 'funds of knowledge' (Moll, Amanti, Neff, \& Gonzalez, 1992) in all communities, and a competency group offers a forum in which these funds can be drawn upon to provide multiple perspectives on a common matter of concern. In the PETRA study, a competency group was used to bring together the knowledge and expertise of the research team, teachers in the schools, and the various funds of knowledge in the school communities. We see this approach as one step towards reinvigorating democracy and extending the role of citizens beyond 'being dependents on professional knowledge' or simply as 'consumers' of schooling (Ranson, 2018, p. 56).

Adapting the idea of competency groups to the educational objectives of the PETRA project, the Learning Commission brought together a diverse group of community members who met regularly over a period of eight months to gather evidence that would support insights about how schools and communities could provide multilateral 'rich accounts' of educational expectations and outcomes. The Learning Commission also sought, in a democratic way, to provide equal status and opportunity for all participants engaged in the process, enabling them to express their views freely in an atmosphere of mutual respect. In this process, the knowledge of both 'expert' and 'community' funds of knowledge was valued and open conversations were encouraged. In one sense then, this paper describes the process of enabling voice for those in schools and communities (Hirschmann, 1970). Data drawn from the Learning Commission and community voices were used in conjunction with data collected in the other stages of the research project to develop the concept of rich accountabilities.

In what follows, we provide a brief account of education accountability and its manifestation in Australian schooling. We then provide a fuller discussion of the competency group approach that inspired the construction of a Learning Commission, and the relationship between the Commission and the other four stages of the broader research project. Next, we consider the establishment of the Learning Commission and its ways of working with communities. We then summarise four central insights derived from analysis of the Learning Commission data, before conceptualising and illustrating our model of rich accountabilities.

\section{Accountabilities and the Learning Commission}

Since the introduction of the National Assessment Programme - Literacy and Numeracy (NAPLAN) in 2008, Australia has had a top-down, test-based mode of educational accountability. Schools, principals, and teachers have largely been held to account by metrics-based, test performance data. This 
has been of a unidirectional, top-down nature, with the gaze of the politicians, media, public and system leaders focused on the work of principals and teachers, and school test results (Baroutsis, 2016). In Australia, the making public of every school's performance on the government website, My School (myschool.edu.au), is related to the emergence of a quasi-market in Australian schools, which in effect, puts each school in competition with other schools (Lingard, Thompson \& Sellar, 2016). There is a plethora of research evidence to indicate the impact of this reductive, perhaps even anti-educational, mode of accountability on the width of curriculum, and indeed, of the quality of schooling provided to all students (e.g. Nichols \& Berliner, 2007).

As such, within the cognate literature, there have been various attempts to reconceptualise educational accountability to militate against the reductive effects of test-based accountability. These include what have been referred to as intelligent, genuine and rich accountabilities (Biesta, 2004; Darling-Hammond, 2010; Darling-Hammond, Wilhoit, and Pittenger, 2014; Lingard, Sellar, and Lewis, 2017; Ranson, 2003, 2012, 2018; Sahlberg, 2007; Sellar, 2015). These approaches differ from the current mode of accountability in that they are inter alia predicated on trust in teacher professionalism. They work vertically in both top-down and bottom-up ways and also function in a horizontal school-to-community and community-toschool manner. These modes of accountability aim to ensure a breadth of curriculum and enriching educative changes to systems, schools, and the work of teachers and principals. They are respectful and inclusive of community expectations and responsibilities in relation to the broad educative work of schools. In Ranson's (2003) account, the 'answerability' created by these alternative modes of accountability operates multilaterally. This includes what Darling-Hammond (2010) and with colleagues (2014) have called 'opportunity-to-learn' standards that enable school communities, school professional staff and students to make upward claims on the 'system' for multiple kinds of resources necessary to achieve the performance demands the system places on them.

Comparisons are central to all modes of accountability and contemporary modes of governance (Ozga, 2009), and Stengers (2010, 2011) has argued that there are ethical and political challenges associated with any comparisons. Importantly, Stengers (2011) observes that 'comparison must not be unilateral and, especially, must not be conducted in the language of just one of the parties' (p. 56). The unilateral establishment of the criteria for comparison, and the act of comparison, is potentially unethical. When applied to the dominant vertical top-down test-based accountability, one can see potentially a number of ethical issues in respect of how schooling ought to function in a democratic society. We would see Stengers's observations as offering a critique of the extant mode of accountability, and a justification for seeking to establish multiple modes and directions of answerability, including multiple voices. 
In reporting on the PETRA project, and focusing on the work of the Learning Commission, we document the basis for constituting a model of rich accountabilities that enables multiple modes and directions of answerability and the inclusion of multiple voices in contemporary schooling in democratic societies. We are not rejecting the potential usefulness of test data, but we argue very strongly that these metrics must be situated in a sophisticated way, within their complex contexts, and must encourage mutual responsibility between schools and their communities, other schools, and regional/central offices (Brennan, Zipin and Sellar, 2016). We suggest that rich accountabilities also demand open discussion about the character of the assessments and metrics to which schools, principals and teachers are held to account, in order to avoid unilateralism (Lingard et al., 2017; Sellar, 2015).

\section{The PETRA study}

There were five stages to the PETRA project ${ }^{2}$, ultimately geared towards developing an alternative form of rich accountabilities. The focus of this paper is on stage three, the work of the Learning Commission and how this contributed to our conceptualisation of this new mode of multidirectional accountability; however, all stages are identified to indicate the progression of the project and interwoven aspects of the stages.

In the first stage, the research team worked collaboratively with a range of stakeholders to develop case studies of eight schools. Through site visits, interviews and school policy analysis, we documented existing knowledge and accounts of student learning and the effects of existing accountabilities in schools. This stage of the project also sought rich information about resources and needs for supporting learning in the regions surrounding the schools. The school case studies indicated deep concern amongst principals and teachers about the narrowness of the empirical data to which they were held to account. They were also concerned about the antieducative effects of this mode. They wanted to be able to talk about the achievements of their schools in more expansive ways and to have these acknowledged by the education system. For example, after her school was flooded and closed for two weeks, one principal advertised in the local newspaper asking for volunteers over the weekend to clean-up the school. About a thousand people showed up to help. This principal argued this was an important manifestation of the esteem in which her school was held in its community. She thought a narrative about this example would be a useful mode of horizontal accountability - school-to-community and the community-to-school — and also a vertical bottom-up mode of giving an account of the school's achievements to the system. Likewise, many of the schools worked assiduously to have positive stories about their schools published in the local newspaper to demonstrate their achievements to their

\footnotetext{
${ }^{2}$ For further details about the community in which the schools were located and about the PETRA project, see Baroutsis (2016) and Brennan et al. (2016).
} 
communities (Baroutsis, 2016). One school had increased quite substantially the number of Indigenous students attending. The principal argued that this reflected positive changes in the school's practices in respect of Indigenous culture and Indigenous communities; for example, acknowledgement of country and inclusion of Indigenous dance in all assemblies; liaison with the local Indigenous community; inclusion of Indigenous perspectives in the curriculum etc. This, it was argued, was another manifestation of horizontal accountability to the community.

In the second stage of the project, workshops were provided to support teachers to design and implement rich approaches to teaching, learning and assessment as part of the community-focused History curriculum units. Student-researchers helped to identify resources that could be used to connect school learning with the needs and aspirations of the communities the schools served. The findings from student research projects, as well as students' and teachers' experiences of working with community members and community knowledge in curricular ways, were included as one important set of rich accounts that were gathered by the Learning Commission.

In the third stage, we convened a Learning Commission, which brought together a group of community members to inquire into what communities in the area expected of schools, what resources were required to meet these expectations, and how communities would know if their expectations were being met. The Learning Commission process expanded the conversation about how schools could develop rich accounts of their achievements, including contributions from a broader cross-section of community members. Submissions and presentations were given to the Learning Commission by the teachers and students involved in the second stage, as well as from principals and a range of community groups. The original aim of the project was to undertake both school and community ethnographies to come to an understanding of their funds of knowledge (Moll et al., 1992). Time and funding prohibited the conduct of fulsome community ethnographies. The work of the Learning Commission, which was managed by community representatives and which invited contributions from multiple community groups, served as a surrogate for community ethnographies, enabling us to tap into community funds of knowledge.

The fourth stage of the project involved attempting to synthesise the data collected from the first three stages, and in the fifth and final stage we utilised these data to conceptualise a concept of rich accountabilities that involved interrogating and translating the understandings derived from the previous four stages, particularly the contributions and insights of the Learning Commission. 


\section{Establishing the Learning Commission}

The PETRA Learning Commission constituted a local experiment in gathering 'rich accounts' about schooling and functioned as a competency group. The research team purposefully established the Commission so that it was representative of a broad range of relevant community groups, including school, education system, and local political leaders, as well as community, media and Indigenous groups. The Commission ensured that Indigenous voices were included in their investigative work through the membership of an Indigenous teacher and in submissions to the Commission. Researchers from the PETRA project team attended all Learning Commission meetings and acted as a secretariat to the Commission, providing support or comment as requested, as well as synopses of relevant research. The Learning Commission was chaired by a former school principal with extensive experience working in the region. The other members of the Commission included a member of the Regional Council, with responsibility for the Community Services Portfolio; a community development worker from the region; a journalist and subsequently editor of the local newspaper; an Indigenous teacher responsible for Embedding Aboriginal and Torres Strait Islander Perspectives in Schools (EATSIPS); and the then Director of Strategic Policy and Research, Department of Education. Collectively, this group constituted the Commissioners who undertook the work of the Learning Commission. The Commissioners came to the project with their own views on schooling and accountability and these were also canvassed and discussed.

The Commissioners sought opinions from a range of groups, including parents and caregivers, principals and teachers, students, community groups, Indigenous elders and business people. These groups were identified as community representatives or 'expert witnesses', who were able to help the Learning Commission with its deliberations. An invitation to participate in the Learning Commission was published in the local newspaper and distributed in school newsletters, a website was established to enable community members to express interest in talking with the Commission. Alongside this process, the Commissioners compiled a list of possible expert witnesses. Expert witnesses, both professional and community, were also invited on the basis of pre-existing relationships with Commissioners or connections to the PETRA project. Students involved in the community history projects in stage two also contributed their insights, along with their teachers.

The Learning Commissioners developed the following guiding questions, in consultation with the PETRA research team:

- What do communities expect from schools?

- How do communities know if expectations are being met?

- How can schools provide reliable evidence of meeting expectations? 
A limitation of the Learning Commission's approach to data collection was the small number of parents who were interviewed by the Commission. An attempt was made to organise community consultation meetings on two separate days at a central venue. However, after extensive publicity through a range of school-based channels and the local media, only two parents indicated willingness to attend the events. This difficulty engaging with parents is not uncommon and reflects the complexities of contemporary work and family life, which can leave little spare time for attending such events (Tate, 2010; Lareau, 2011; Epstein \& Sheldon, 2016). The principals indicated to the research team that this was also their experience when trying to get parents to attend school meetings (see Community access and involvement section below). They indicated they had much better responses from parents through online communications, thus the development of the PETRA website to enable online submissions to the Learning Commission. Parents' reluctance to attend school events may also reflect their own negative experiences of schooling (Tate, 2010; Lareau, 2011).

Six Learning Commission meetings were held across the second half of 2013 and into early 2014. These meetings varied in purpose and structure. Four open meetings were held in which different educational stakeholders shared their views with the Learning Commission. Two closed meetings were also held; the first was to establish the Learning Commission process (August 2013) and the second was used to reflect upon the process at its culmination (May 2014). A senior leader from the Department of Education (a representative of the Director-General) attended this last closed meeting where community and school leaders were able to speak back to the system about their experiences and make demands for the necessary support required to achieve the outcomes expected of them - 'opportunity-to-learn standards' (Darling-Hammond, 2010, p. 310). Thus, the process culminated in school staff giving alternative accounts to those who usually hold them to account.

During three of the open meetings, the Learning Commission interviewed a range of representatives from groups including parents, the regional corporation for Indigenous women, the disability care sector, charities, youth workers, small business owners, bank managers, school students, teachers and principals. These participants were drawn from communities in the major towns in the region. The format for open meetings involved the Commissioners asking predefined questions of the invited participants and engaging in conversation about issues of importance to participants in relation to schooling. This meeting also gave an opportunity for community leaders to establish the basis for future horizontal relationships with schools in their communities and vice-versa.

The third open meeting varied in format from the previous two open meetings. This event brought together two aspects of the project: (a) the Learning Commission inquiry process and (b) the curriculum work conducted by teachers and students. Teachers from three schools presented with a small group of students on community-based research conducted as part of the 
History curriculum. Learning Commissioners asked questions of teachers and students following each presentation. After three open meetings had been held, a closed meeting was convened to reflect on the process. The Learning Commissioners discussed key narratives that had emerged and the strengths and weaknesses of the process. This meeting also addressed the challenging issue of recruiting parents. The fourth and final open meeting of the Learning Commission involved a conversation between the Commissioners and three principals of schools in the region.

\section{Conducting research with the community}

All six Learning Commission meetings were recorded and transcribed, and the meetings generated a data set with some clear accounts. However, it is important to acknowledge that there are groups and perspectives that were not able to be included in this process. We analysed data using a narrative inquiry perspective (Clandinin \& Connelly, 2000), where the participants' experiences are 'expressed in lived and told stories' (Pinnegar \& Daynes, 2007), thereby detailing their 'rich accounts'. The narrative inquiry approach to data representation has three dimensions that focus on 'temporality (past, present, future), sociality (the dialectic between inner and outer, the personal and social), and place (the concrete physicality of the place or places in which experiences are lived out and told)' (Clandinin, Murphy, Huber, and Orr, 2009, p. 82).

This approach aligns with the funds of knowledge perspective that recognises the existence of rich cultural assets for learning in all communities and all families, regardless of socio-economic advantage or 'disadvantage' (Moll, 2014). While this three-dimensional approach enabled the development of situated 'rich accounts' from all participants, it also acknowledges the unique position of the researchers in the Learning Commission. We note that submissions to the Learning Commission were not treated as research interviews, but rather as collaboratively produced accounts. During the Learning Commission, the researchers were also participants in the process, as was the chairperson of the Learning Commission and the other Commissioners. The views of the researchers and Commissioners became incorporated into the inquiry, working alongside the lived experiences of the participants (Clandinin et al., 2009). The views of the Commissioners shaped participant selection, and the types of questions that were asked during the Learning Commission meetings. Along with analysis of data from the earlier stages of the project, the Learning Commission process and data enabled and facilitated the development of the concept of 'rich accountabilities'. Additionally, this narrative perspective enabled the researchers to identify 'competing stories' about schooling and education; that is, stories that 'live in dynamic but positive tension with dominant stories of school whereas conflicting stories collide with dominant stories of school' (Clandinin et al., 2009, p. 82). 


\section{Analysis of Learning Commission data and the production of narrative accounts}

The accounts derived from the Learning Commission data have been grouped into four narratives. These are: (1) suggested reforms of system-wide practices and revision of performance measurement and funding expectations by education system authorities; (2) alignments and gaps between community expectations and schools; (3) increased community access and involvement to support schools, children and young people; and (4) meaningful teaching and learning practices. Each of these narratives will be discussed below, drawing on Learning Commission data.

\section{System-wide practices}

System-wide practices, drawn from understandings of regional, state and federal government reforms in education, were a site of struggle. In relation to such sites, Ball (2006) suggests, '[t]he issue of who controls the field of judgment is crucial. One key issue of the current educational reform movement may be seen as struggles over the control of the field of judgment and its values' (p. 144). Ball (2006) defines performativity as 'a technology, a culture and a mode of regulation that employs judgments, comparisons and displays as a means of incentive, control, attrition and change - based on rewards and sanctions (both material and symbolic)' (p. 144). The prevailing system-wide practices followed this approach by tying numerical data on performance to funding and governance practices. Discussions about systemwide practices emphasised the lack of shared expertise and infrastructure; issues of equity in funding practices; and the use and effects of performance measurement in schools and systems.

Principals collectively raised concerns about the possible emergence of what they saw as a schooling system in which much responsibility was devolved to the school without commensurate power or systemic supports. Furthermore, principals felt that the system saw their schools as individual entities in competition with other schools. One principal gave the following example:

Currently in this town, in terms of managing behaviour, we have started a trial of three clusters of schools coming together and managing [resources]. Now, that was all very fine when it was a regional resource, they said, "Yes, you could do that." ... You know, we would all be given a bit of a parameter about how we make the decision but what was re-enforced to us was that it's a principal's decision about that. So, what's been taken away is that sort of system of "this is how we make this stuff operate and work", throwing back to schools and almost saying, "Well, you almost have to work that out for yourselves, how you want to work together". And that's why this working 
relationship is vital, in the community, for your community, for the greater community.

There is international support for such community-based approaches, with Ozga (2012) suggesting that traditional, bureaucratically-organised and controlled systems have been replaced by 'networks of relationships in which cooperation and coordination must be constantly negotiated and managed' ( $p$. 440). The principals described the importance of negotiation, cooperation and support between schools and communities, and particularly in rural and regional school communities. They saw their desire to collaborate with other schools sitting in tension with the systemic focus on individualising schools and driving competition between them.

The principals raised a number of concerns about what they saw as a move towards a 'systemless system' (Lawn 2013) and a lack of shared infrastructure. The principals talked about the fact that their schools were at the very northern periphery of their region, which meant that they had considerable autonomy and incentives to work together, as noted above, but also reduced support and visits from the regional office. One principal noted the reduction in regional support for the schools:

Those managers that used to do all of this from the regional office are gone. So, all that work that was done ... Now we have to do it. Nothing will support us to do it. We are just being asked to do it. ... more and more of the responsibilities and accountabilities ... are being thrown on principals ... [who] don't have the skills. And there is no training, at this stage.

Another concern related to the level of expertise required to make many of the operational decisions that are now devolved to schools and principals. One principal explained:

And that then puts back onto schools that sense that "you are going to need to know everything and be very well researched and know a lot of stuff about things", whereas that expert sitting out there can actually come and help me with that stuff.

In relation to English schooling, Lawn (2013) argues that it is now only the centre that has a feel for what the system is and that this is basically constructed and made legible through data that the system has available to it to create a panoptic view. Specifically, Lawn situates this systemless system in relation to New Public Management principles and the enhanced significance of policy as numbers and data infrastructures for managing and running schools and systems. Lawn notes,

The tendency of New Public Management to focus on efficiency, productivity targets and strategic capacities allows the system to be reimagined through data and, indeed, allows the centre to shape, direct 
and steer a system that only it fully determines and views as a single, complex system. (Lawn, 2013, p. 232)

We saw very similar dynamics evident in the PETRA study, as illustrated in the principals' view that they no longer felt they were part of a coherent and cohesive schooling system and that they were responsible for more things but with limited systemic support.

\section{Community expectations}

When eliciting community expectations of schools held by a diverse group of stakeholders, it is understandable that there would be competing views with regard to what schools should, and could, be doing. This was the case when the Learning Commission consulted stakeholders including school system authorities, school leaders and teachers, parents, employers, politicians, or journalists. In addition to the previously noted lack of alignment between school-specific and system-wide expectations, we found differences between the desired outcomes of community stakeholders and the accountability imperatives of the system and governments.

Community expectations centred on two issues: community partnerships between school principals and employers, and the need for schools to support employers' perspectives on schooling outcomes. Of note here is that employers were cognisant of the 'self-interest' associated with many of their expectations of schooling and the value placed on the links between businesses and local schools. Effective partnerships were considered to be those that moved beyond self-interest to relationships that yielded broader benefits for young people, as well as reciprocal benefits for both schools and local businesses. Local community members also noted that there was a perception that for students to be regarded as successful, that they had to leave the local community.

One Commissioner raised the point about maintaining a balanced focus on the outcomes of schooling, including social, emotional and academic, placing the child or young person at the centre of this focus. There was concern that top-down test-based accountability, as manifested in the work of the My School website, tended to give greater emphasis to improving test scores than to other non-cognitive purposes of schooling. This Commissioner commented,

I think the thing that correlated around everything is: despite the media, despite the hype about My School ${ }^{3}$, about a million other things, the thing that was consistent was [a focus on] 'positive culture, support, how do we balance it? One being tossed out against the other? Can we

\footnotetext{
${ }^{3}$ The My School (myschool.edu.au) website makes public a range of school-level data about every school in Australia, including the aggregated school results of the National Assessment Program.
} 
get the best of both worlds?' That surprised me with the employers. Even though I would absolutely agree with them, it really, really surprised me that the employers wanted to know that. It really didn't surprise me with the parents. With most parents, you want your kids to be happy and secure.

This Commissioner noted how media tend to focus on measured and published criteria comparing school 'success or failure' in terms of literacy and numeracy test scores and other academic results (with funding implications). This Commissioner also had the impression that employers would have a similar focus to that of the media or government. Contrary to this impression, the business stakeholders foregrounded the importance of caring for children and young people in schools and the understanding that there needs to be a balance between academic success and supporting students' socio-cultural and interpersonal needs. Learning Commission dialogue thus pushed beyond media, political, and accountability simplifications, towards recognition of the greater complexity in which different stakeholders understood the various purposes of schooling. Schools that interact with, and enlist the support of, students, parents and local community members, as well as governments, have greater opportunities to share rich communication in which horizontal accounts from multiple voices are heard and can make a difference to the learning process (Lingard, 2014).

In the Australian context, the introductory statement of the Alice Springs (Mparntwe) Education Declaration (Education Council, 2019) emphasises that education should support young people by helping them develop the skills needed to participate in the economy and engage in society. ${ }^{4}$ Additionally, goal two of the Alice Springs Education Declaration promotes active and informed community members (Education Council, 2019). Employers, business leaders, and community workers who participated in the Learning Commission gave strong accounts of their perceptions in relation to schools developing work-ready citizens, who had the necessary skills, including numeracy and literacy, particularly reading and writing (including handwriting ${ }^{5}$ ). In addition to such academic skills, business leaders also considered personal and interpersonal skills a very important element of work-readiness. These skills included,

... effective personal presentation skills and social etiquette; refined communication skills such as listening and speaking; resourcefulness in

${ }^{4}$ The Alice Springs Education Declaration articulates goals for all Australian schools as agreed to by all education systems and the federal government. It builds from earlier such Declarations, the most recent of which was the Melbourne Declaration of 2008.

${ }^{5}$ The study was conducted in a rural/regional part of Queensland; therefore, we note that perceptions of these social skills might be articulated in different ways across the nation. We were surprised at the emphasis given to handwriting in this digital age. 
terms of knowing how to gain knowledge and access to various resources, for example, Centrelink; ${ }^{6}$ basic life skills such as following instructions or operating a microwave; and had developed selfdiscipline strategies and skills.

This list of work-related skills and practices suggested by the Commissioners goes beyond the quite specific expectations for education provision in an already crowded curriculum.

In addition to the view that school-community partnerships should be supported and encouraged, the issue of negative community perceptions of schools and children was raised by the Commissioners and the school principals. As previously shown, one Commissioner suggested that community perceptions were often formed through media coverage of education issues: 'I didn't believe the good that [the school] was doing in the community was actually being presented properly through the media'. Negative media coverage is likely to frame public perceptions of school communities, and of the staff and students within these communities (Baroutsis, 2016). In interviews undertaken outside of the context of the Learning Commission, one principal told us about being 'front paged', referring to the negative experience of the school being lambasted on the front page of a newspaper. Fiske (2011) suggests that such media accounts are never neutral; therefore, while media coverage of a school can, at times be 'positive' and supportive of school practices, it is the negative coverage that can cause the greatest harm and is difficult to ameliorate once in circulation. The Commissioners mostly spoke of their disapproval of the negative coverage of their schools and communities,

There is the outside reporting, that most often comes through the printed media or the visual media, and, of course, social media. Sometimes that's good, sometimes it is not so good. I think schools are manic about negative reports. They don't like them and, of course, for all sorts of good reasons.

The concern here was that coverage was often simplistic and/or distorted.

There was also discussion as to what schools and communities could do to counter these negative perceptions. While many members of the school communities acknowledged that in-house publications such as school websites and newsletters were able to promote the positive aspects of schools, this did not go far enough in terms of disrupting the, at times, unwarranted and negative community perceptions. Consequently, adopting a rich accountability approach created possibilities for bringing community members into dialogue with school staff in a more systematic and nuanced way. This was the case during the Learning Commission, which included a

${ }^{6}$ Centrelink is an Australian Government agency responsible for the delivery social, health and child support services and payments for a variety of groups including the unemployed. 
member of a key local media organisation. In turn, these relationships can do much to help the wider community appreciate the complex realities of schools.

\section{Community access and involvement}

The Learning Commission also heard accounts that detailed the need for equal access and opportunities for participation for all parents and students in school communities. Parental involvement can operate as a mechanism of mutual accountability (Sahlberg, 2010), or relational two-way horizontal accountability, in relation to the educational outcomes of the children and young people in schools (Lingard, 2014). In accounts presented at the Learning Commission, concern was expressed at the absence of parental involvement in schools. For example, a member of the Indigenous community commented about the 'drop-and-go' mentality of many parents and care-givers. In another example, a principal noted:

When everything is going fine, you don't make contact with them [parents]. You don't see them. They come to parent/teacher interviews; kids are doing well. You don't see those people.

This is not to say that we, nor the individuals who spoke at the Learning Commission, understood members of the community in deficit ways. Rather, the argument was made that more inclusive and richer dialogue was needed to understand community and parental perceptions. There may be countless reasons why parents do not participate in their children's school community, including busy lives and work commitments, or they may find the school environment in some ways alienating or daunting. As noted by a Commissioner, the parental disengagement may indicate a lack of agency on the parents' part, or not feeling welcome as members of the school community. Schools need to be very proactive to create a welcoming environment.

One possible cause of parental disengagement within school communities that was raised at the Learning Commission, along with ways of addressing it, specifically referred to schooling practices that value cultural diversity. In one account given by members of an Indigenous community, it was suggested that it was important that schools acknowledge and raise cultural awareness. The Indigenous women who presented to the Learning Commission indicated that they had observed improvements over the years with an increasing number of graduate teachers and school communities demonstrating greater awareness of Indigenous peoples and their cultures, with some schools in the region having specific cultural programs in place. This suggests that knowledges relating to a non-dominant culture's beliefs, languages, or practices are being valued at such schools (Hayes, Mills, Christie, \& Lingard, 2006, p. 68). Additionally, it was suggested at the Learning Commission that such enrichment programs encouraged enrolments 
and attendance in schools. They also encouraged better school-community relationships.

As well as the recognition of cultural diversity, the Learning Commission raised associated problems with not recognising socio-economic diversity within school populations. Socio-economic differences were raised in accounts that focused on the costs associated with students' participation in schooling. A Commissioner indicated, '[i]t is expensive now to participate in school; it's expensive now to participate in the cultural activities'. While government schooling is often discussed as 'free' schooling, the Commissioners highlighted a range of escalating costs associated with students' participation in sporting and cultural activities, sometimes with little acknowledgement of the diverse socio-economic backgrounds within the community. The Commissioners suggested that these extra costs were often prohibitive of participation by some, which in turn had a number of flow-on effects and consequences for schools and communities. Research by Holt, Kingsley, Tink, and Scherer (2011) suggests 'participation [in sport] has been correlated with numerous positive developmental indicators, including improved self-esteem, emotional regulation, problem-solving, goal attainment, social skills, and academic performance' (p. 490). However, their research also indicates that financial obstacles in 'disadvantaged' or lowincome communities often restrict a child or young person's participation in school sporting activities (Holt et al., 2011). This issue was also raised by many parents and students during Learning Commission discussions.

Practices that limit opportunities for individual and community involvement in schooling require further investigation and work to develop initiatives that enable engagement across multiple sites and actors. For example, we found that teachers' curriculum interventions that were part of stage two of the project demonstrated creative and productive ways to engage parents and communities in schools and students and teachers in communities. For example, the student projects in stage two saw community members coming into the schools and working with teachers and students.

\section{Meaningful learning}

Accounts provided to the Learning Commission also focused on teachers and teaching, and these accounts supported the view that an 'opportunity-tolearn' framework was helpful in supporting the attainment of positive learning outcomes. Darling-Hammond (2010) defines opportunity-to-learn standards as specifying:

...the opportunity-to-learn the curriculum assessed in state standards, access to the resources needed for success in the curriculum - such as teachers who are well qualified to teach the curriculum, appropriate curriculum materials, technology, and supportive services - and access to other resources needed to succeed in school and life. (p. 310) 
Opportunity-to-learn standards assume that schools and their communities should be provided with the financial and material resources necessary to achieve the teaching and learning requirements that are demanded by a system. This is an upward vertical mode of holding those in power to account as a complement to top-down, test-based accountability.

Many of the accounts given by students who participated in the Learning Commission drew upon their personal reflections on recent learning experiences at their schools. When discussing their learning, many of the students indicated they valued meaningful or 'authentic' learning experiences and suggested that these helped them to learn. Approaches that utilised 'authentic experiences' in teaching, the curriculum, and assessmentauthentic in the sense that intellectual and practical skills are 'transferable' to 'real-life' social settings and work environments (Darling-Hammond, Ancess, \& Falk, 1995) - can be more effective than abstract learning tasks (Hargreaves, Earl, \& Schmidt, 2002). Students suggested that authentic approaches to learning included group work, hands-on activities, multi-modal tasks and engagement with their communities that draws on local knowledge, as in stage two of the PETRA project.

For example, some of the students described a history unit that incorporated local knowledge through project-based learning. Students participated in school-based projects designed and developed by teachers at each of the participating schools. The teachers planned learning activities for their students that utilised local knowledge and raised community awareness by drawing on past experiences within the community to explore an historical event. Of this learning approach, one student stated:

... I think getting to speak to someone who actually experienced it, helps you to understand it a lot more. Getting to know actual stories, not just reading about something and trying to picture it...

Such accounts illustrate that people's experiences, including those who may be materially or economically 'disadvantaged', are rich in cultural and historical knowledge.

The students who participated in the Learning Commission also indicated that having teachers who understood them, and their preferred methods of learning, was important. Similarly, many of the parents indicated that they valued 'caring teachers' who made 'challenging demands' of their children so as to encourage, promote, and facilitate learning. As Noddings (2003) suggests, teaching is a 'relational practice' with teachers engaged in 'relations of care and trust' (p. 250). Positive relationships between teachers and students, such as those expressed in the Learning Commission, are more likely to result in meaningful learning. As suggested by the OECD:

Students tend to thrive when they form positive relationships with peers, feel part of a social group, and feel at ease at school. A lack of connectedness can adversely affect students' perceptions of themselves, 
their satisfaction with life, and their willingness to learn and to put effort into their studies. (OECD, 2013, p. 51)

Many of the teaching approaches identified during the Learning Commission draw on the funds of knowledge perspectives and support the view that there is, in every community, 'historically accumulated and culturally developed bodies of knowledge and skills' (Moll et al., 1992, p. 133). This approach acknowledges that communities hold rich perspectives on knowledge and that this matters, both within a school and a local community, and beyond. Such approaches reject deficit accounts of communities and schools in disadvantaged areas. Rejecting deficit approaches is central to opening-up productive horizontal school-community, community-school relationships.

\section{Rich accountabilities}

We drew on the Learning Commission discussions about system-wide practices, community expectations, community access and involvement, and meaningful teaching and learning to develop a richer theorisation of educational accountability. Rich accountabilities are part of a new wave of thinking and conceptualisation about accountabilities in school systems that need to work in more productive, effective, educative, and democratic ways. While most modes of accountability focus on being held to account, rich accountabilities also value opportunities to give accounts, thereby changing the relationship between those who give the account and those who receive, and often judge, the account. This involves rethinking what we mean by accountability, reclaiming the ethical sense of 'giving responsive accounts', which address the complex ways in which schools and systems are working in the contemporary environment. Rich accountabilities enact different types of relationship across different parts of the system, with everybody taking responsibility for providing multiple forms of data, complex analyses and appropriate actions.

Rich accountabilities serve equity goals by (a) providing alternatives to accountability practices that can unfairly narrow the focus of curriculum and pedagogy for some students in an effort to improve testing performance; (b) making visible a broader spectrum of what schools achieve for students; and (c) taking account of community 'funds of knowledge' as assets for learning, as well as students' and families' needs and aspirations, in order to provide better evaluations of school and systemic performance and the equitable allocation of resources. Below is a visual representation of rich accountabilities, as conceptualised from data analysis of the Learning Commission's work, and analysis of the other data in other stages of the project (Figure 1). 


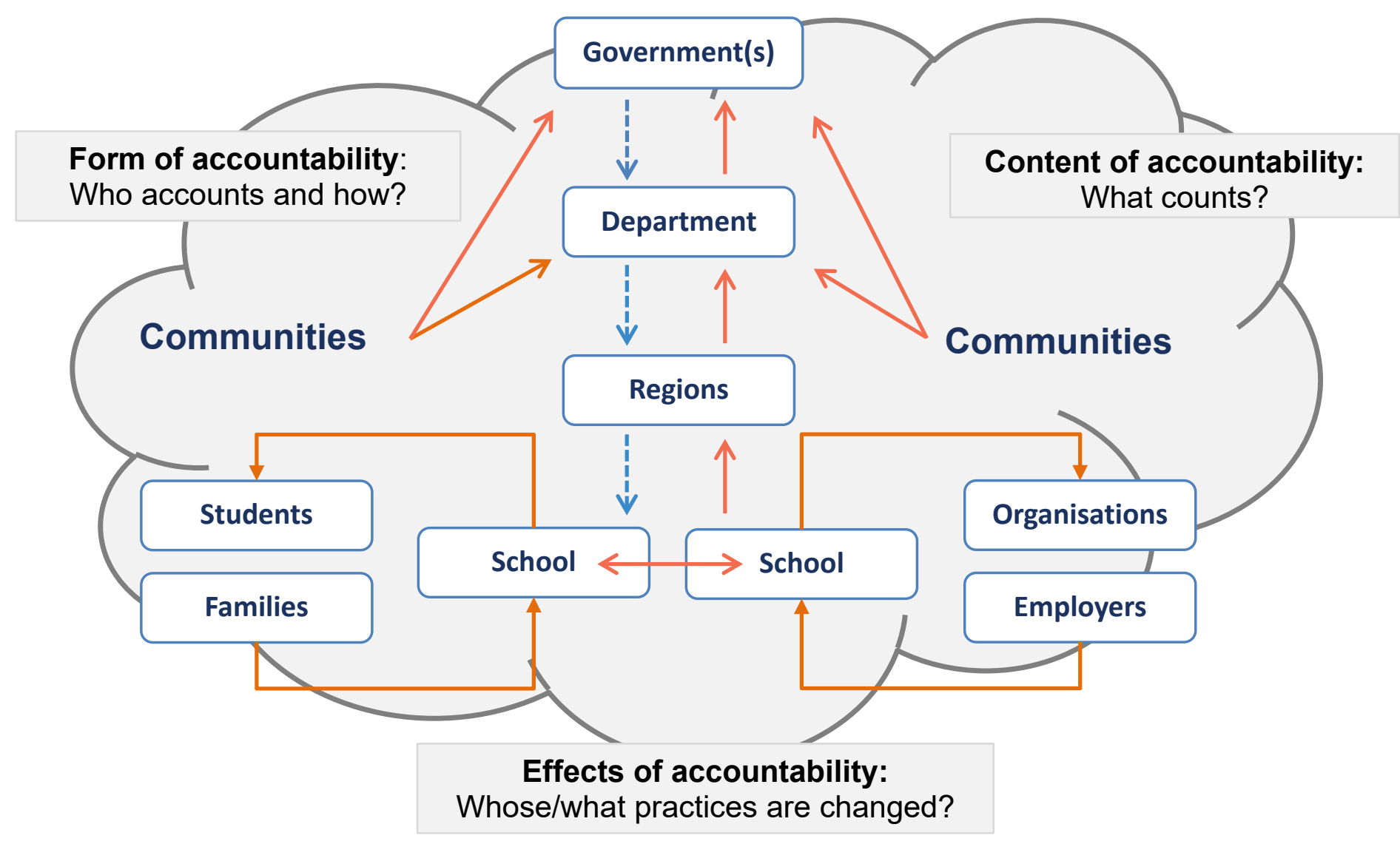

Figure 1: A conceptualisation of rich accountabilities

Questions about the form, content, and effects of accountability can be asked of any accountability system; however, when understood through a rich accountabilities framework, we note the following. The questions of the form of rich accountabilities focus on the actors involved in giving accounts. Rich accountabilities differ from current modes of accountability that are generally vertical, unilateral, and top-down, in a path from governments/systems to schools (Figure 1, dash arrows). Rich accountabilities are multilateral and multidirectional in character, incorporating vertical bottom-up and horizontal dialogues (Figure 1, solid arrows). Rich accountabilities imply an opportunity for schools, students, and their communities to speak back to central authorities and policy in relation to what they need to achieve systemic and school goals. They also imply the necessity of systemic learning and dialogue, which involve listening and capacity for flexibility as the basis for action at the appropriate level. This form of accountability allows for systems to learn and in so doing improve policy, the targeting of funding and support for schools, cognisant of the fact that education is about supporting young people and maximising their learning.

The question of the content of accountability relates to how judgments are made about what counts. The dominant top-down mode of 
accountability focuses on standardised tests and other measures and comparisons (e.g. NAPLAN, end of school scores, school audits, teaching and learning audits). Rich accountabilities give consideration to other elements as complementing that mode. This includes a vertical form of accountability, but also a bottom-up one: the opportunity-to-learn standards that Darling-Hammond (2010) suggests are able to 'secure more equitable education' as they 'attend to the opportunity gap as well as the achievement gap' (p. 310). Performance against these standards can be assessed using both quantitative and qualitative data. These data are about articulating for the system what schools and their communities see as necessary for schools to achieve the broader goals the system has set (e.g. for Australian schools the Alice Springs Education Declaration). In addition to vertical modes, rich accountabilities involve horizontal accounts given between schools and communities regarding the expectations and responsibilities of both. We use communities here to signify the diversity and multiplicity of communities that schools need to interact and work with. This horizontal mode might include formalised qualitative data and situated and singular narrative accounts that arise from, and are illustrative of, school-community relationships and broader school achievements, with the scope for narrative accounts to be moderated in ways that enable comparison regionally and systemically.

The final question relates to the effects of accountability, asking whose and what practices should be changed. Top-down, test-based modes of accountability direct attention to schools, teachers and students as the targets of performance measurement and improvement. Rich accountabilities expand the perspective on educational change to see schools as situated in networks that span multiple scales, with giving accounts and holding to account involving a more diverse set of agencies. Rich accountabilities thus open the possibilities for changing systemic practices and the practices of both schools and communities as they interact, mobilising multidirectional opportunities for changes in accountability practices in educative ways.

Rich accountabilities thus involve debates about what counts and what should be counted in schooling. Rich accountabilities involve more people in the constitution of the fields of judgement, thus making them more democratic and avoiding unilateralism. Rich accountabilities also draw on the perspectives of multiple stakeholders, including the voices of students and families who are 'least advantaged'. Rich accountabilities draw on multiple data sets in various forms (quantitative and qualitative) to provide complex, contextualised and balanced assessments of teaching and learning and accounts of the broader (academic, social, cultural) achievements of schools. When undertaking education reform to develop rich accountabilities, eight key areas need to be considered (see Table 1), with the goal of informing educational practices and improvement in respect of both performance and equity within schools, regions and systems. 
Table 1: Eight key ideas of rich accountabilities

\begin{tabular}{|c|c|}
\hline Focus & Key ideas \\
\hline \multirow{3}{*}{$\begin{array}{l}\text { Democratic processes } \\
\text { and dialogue }\end{array}$} & $\begin{array}{l}\text { Multilateral - involving all partners and } \\
\text { stakeholders }\end{array}$ \\
\hline & $\begin{array}{l}\text { Multidirectional - horizontal, vertical and } \\
\text { reciprocal }\end{array}$ \\
\hline & $\begin{array}{l}\text { Processes of accountability are more } \\
\text { inclusive, dialogical and productive }\end{array}$ \\
\hline \multirow{2}{*}{$\begin{array}{l}\text { Learning goals and } \\
\text { domains }\end{array}$} & $\begin{array}{l}\text { Equity and performance - promote learning } \\
\text { for all }\end{array}$ \\
\hline & $\begin{array}{l}\text { Consider multiple domains of learning } \\
\text { including academic, social, emotional and } \\
\text { career aspirations }\end{array}$ \\
\hline \multirow{3}{*}{$\begin{array}{c}\text { Collecting and } \\
\text { interpreting } \\
\text { accountability data }\end{array}$} & $\begin{array}{l}\text { Debate concerning what data are collected and } \\
\text { for what purposes }\end{array}$ \\
\hline & Debate regarding interpretation of data \\
\hline & $\begin{array}{l}\text { Student viewpoints and aspirations are } \\
\text { foregrounded }\end{array}$ \\
\hline
\end{tabular}

Our conception of rich accountabilities raises a number of considerations in terms of improving practices. Many education systems now value quantitative data that can be collected at large scale and which allow for evaluative comparisons. However, schools do much important work that is not captured by data of this kind. What becomes valued by systems is generally what is measured by systems, but this does not necessarily match community expectations of schooling, as shown by the Learning Commission. Schools and systems need mutually developed and agreed processes that make publicly visible the broad achievements of schools and school communities. These accounts should respond to community values and expectations in relation to schooling. However, there are some important caveats in respect of these principles. Rich accountabilities must not intensify the work of principals and schools and must have as their goal improved learning for all and more equitable outcomes. We concede, though, establishing rich accountabilities will be time-consuming to develop. At the core of this change process is building trust that enables more fulsome involvement of teachers, students along with parents and communities.

\section{Concluding remarks}

The rationale for the Learning Commission was a funds of knowledge view of communities and an acknowledgement that enriching school/community relationships will enhance the quality of schooling provided. As Vygotsky observed: 
Ultimately only life educates, and the deeper that life, the real world, burrows into the school, the more dynamic and the more robust will be the educational process. That the school has been locked away and walled in as if by a tall fence from life itself has been its greatest failing. Education is just as meaningless outside the real world as is fire without oxygen, or as is breathing in a vacuum. The teacher's educational work, therefore, must be inevitably connected with his [or her] creative, social and life work. (Vygotsky, 1997, p. 345)

The 'rich' conversations that were had during the Learning Commissions enabled 'horizontal' exchanges of ideas about what 'counts' in education and how schools might report in relation to these purposes. Such exchanges are offered as an alternative to, and as possibilities for improvement upon, the more common vertical and unilateral accountability relationships that exist within education systems.

Increasingly, schools operate within frameworks of New Public Management, network governance and neoliberalism. Couldry (2010) suggests that:

As neoliberal rationality becomes institutionalized culture, it shapes the organization of space. Some types of space become prioritized, others fall out of use and so stop being imagined; because voice is embodied, this matters hugely for the effectiveness of voice, since neoliberalism literally changes where we can and cannot speak and be heard. (p. 12)

Our Learning Commission work, based on the example of 'competency groups', can be seen as part of a broader democratic project that challenges the thinning out of the role of communities and citizens in public life, including in schooling (Ranson, 2018). Following Whatmore's (2009, p. 594) example, the aim of the competency group was to engage with 'a dissonance between the first-hand experience ... and vernacular knowledge accumulated in ... localities' and the perspective on schooling in these localities that is provided by quantitative performance data. This approach challenges the conception of 'citizens as passive spectators bereft of voice and agency' (Ranson, 2018, p. 56).

The Learning Commission began a process requiring ongoing commitment and trust between school communities, parental communities, local communities, research communities, and educational communities. Priority was given to listening to and supporting each other, giving previously 'silenced' stakeholders the opportunity and the platform to participate and be heard. As such, the Learning Commission encouraged and valued a range of voices, creating a space where stakeholders 'can speak' and 'will be heard'. Importantly, this can help to improve the learning outcomes of young people.

The Learning Commission also demonstrated that it is hard work to involve communities in schools. We encountered difficulties with accessing parental and community views of schools. We perhaps underestimated how 
long it would take to establish the Commission and get submissions from expert witnesses and others. It takes time to build trust and engage community members in a process of this kind. We believe one reason for the success of the Learning Commission was the trust that was built over the life of the PETRA project between the research team, the schools, their principals and some teachers, and then with the Commissioners. Finally, while we secured local media coverage of key Learning Commission events, in hindsight we see benefit to engaging these media more substantially to solicit greater involvement from that community within the Learning Commission process.

For those who did participate in the Learning Commission, there was very strong support for the attempts to draw schools and their communities closer together. Potentially, this will have positive effects on students' learning and the achievements of schools (Tate, 2012). Overall, there was an appreciative sentiment expressed about bringing together all school and community stakeholders for constructive discussions about how rich accountabilities might be conceptualised and operationalised in the restructuring of schooling systems. There was much support for enabling many voices into these conversations and we became acutely aware of the necessary capacity to engage in active listening as part of processes of policy production and enactment. We conclude with the words of one of the Learning Commissioners, who stated,

I think the benefit of the [Learning Commission] process has actually been the process. When was the last time someone actually asked the broad sector, as the Commission has, what they want, how they feel or how they would like it delivered? When were they last asked that? You might have filled in a survey at school and gone tick - well, those who could be bothered - go "tick, tick", or whatever. But you are actually involving a cross-section of students, a cross-section of teachers and a cross-section of community people, workers, parents. Again, this is probably the first time they have ever been asked. So, if anything comes out of this, it should be further engagement to keep and grow those Commissions.

\section{References}

Ball, S. J. (2006). Education policy and social class: The selected works of Stephen Ball. London: Routledge.

Baroutsis, A. (2016). Media accounts of school performance: Reinforcing dominant practices of accountability. Journal of Education Policy, 31(5), 567-582. doi:10.1080/02680939.2016.1145253

Biesta, G. (2004). Education, accountability, and the ethical demand: Can the democratic potential of accountability be regained? Educational Theory, 54(3), 233-250.

Brennan, M., Zipin, L., \& Sellar, S. (2016). Negotiating with the neighbours: Balancing different accountabilities across a cluster of regional 
schools. In B. Lingard, G. Thompson, \& S. Sellar (Eds.), National testing in schools: An Australian assessment (pp. 199-211). New York: Routledge.

Clandinin, D. J., \& Connelly, F. M. (2000). Narrative inquiry: Experience and story in qualitative research. San Francisco, CA: Jossey-Bass.

Clandinin, D. J., Murphy, M. S., Huber, J., \& Orr, M. (2009). Negotiating narrative inquiries: Living in a tension-filled midst. The Journal of Educational Research, 103(2), 81-90.

Couldry, N. (2010). Why voice matters: Culture and politics after neoliberalism. Los Angeles: SAGE.

Darling-Hammond, L. (2010). The flat world and education: How America's commitment to equity will determine our future. New York: Teachers College Press.

Darling-Hammond, L., Ancess, J., \& Falk, B. (1995). Authentic assessment in action: Studies of schools and students at work. New York: Teachers College Press.

Darling-Hammond, L., Wilhoit, G., \& Pittenger, L. (2014). Accountability for college and career readiness: Developing a new paradigm. Education Policy Analysis Archives, 22(86), 1-38.

Education Council. (2019). Alice Springs (Mparntwe) Education Declaration. Retrieved from: https://docs.education.gov.au/system/files/doc/other/final__alice_springs_declaration__17_february_2020_security_removed.pdf

Epstein, J.L. \& Sheldon, S.B. (2016). Necessary but not sufficient: The role of policy for advancing programs of school, family, and community partnerships. The Russell Sage Foundation Journal of the Social Sciences, 2(5), 202-219.

Fiske, J. (2011). Reading the popular ( $2^{\text {nd }}$ ed.). Abingdon, UK: Routledge. Hargreaves, A., Earl, L., \& Schmidt, M. (2002). Perspectives on alternative assessment reform. American Educational Research Journal, 39(1), 69-95.

Hayes, D., Mills, M., Christie, P., \& Lingard, B. (2006). Teachers and schooling: Making a difference. Crows Nest, AU: Allen \& Unwin.Hirschmann, A. O. (1970). Exit, Voice and Loyalty: Responses to Decline in Firms, Organizations and States. Cambridge, MA: Harvard University Press.

Holt, N. L., Kingsley, B. C., Tink, L. N., \& Scherer, J. (2011). Benefits and challenges associated with sport participation by children and parents from low-income families. Psychology of Sport and Exercise, 12(5), 490-499.

Lareau, A. (2011). Unequal childhoods: Class, race, and family life. ( $2^{\text {nd }}$ ed.). Berkeley, CA: University of California Press.

Lawn, M. (2013). A systemless system: Designing the disarticulation of English state education. European Educational Research Journal, 12(2), 231-241. 
Lingard, B. (2014). Reviewing education policy to develop a shared vision of excellence and innovation. Keynote presentation at the Maynooth Education Forum, Ireland, 27 June.

Lingard, B., \& Lewis, S. (2016). Globalization of the Anglo-American approach to top-down, test-based educational accountability. In G. Brown and L. Harris (Eds.) Handbook of Human and Social Factors in Assessment. London: Routledge.

Lingard, B., Sellar, S., \& Lewis, S. (2017). Accountabilities in schools and school systems. In G. Noblit (Ed.), Oxford Research Encyclopedia of Education. Oxford: Oxford University Press.

Lingard, B., Thompson, G., \& Sellar, S. (Eds.). (2016). National testing in schools: An Australian assessment. New York: Routledge.

Nichols, S., \& Berliner, D. C. (2007). Collateral damage: How high stakes testing corrupts America's schools. Cambridge, MA: Harvard Education Press.

Moll, L. C. (2014). L S Vygotsky and education. New York: Routledge.

Moll, L. C., Amanti, C., Neff, D., \& Gonzalez, N. (1992). Funds of knowledge for teaching: Using a qualititive approach to connect homes and classrooms. Theory Into Practice, 31(2), 132-141.

Noddings, N. (2003). Is teaching a practice? Journal of Philosophy of Education, 37(2), 241-251.

OECD. (2013). PISA 2012 results: Ready to learn: Students' engagement, drive and self-beliefs (Volume III). Paris: OECD Publishing.

Ozga, J. (2009). Governing education through data in England: From regulation to self-regulation. Journal of Education Policy. 24: 149162.

Ozga, J. (2012). Governing knowledge: Data, inspection and education policy in Europe. Globalisation, Societies and Education, 10(4), 439455.

Pinnegar, S., \& Daynes, J. G. (2007). Locating narrative inquiry historically: Thematics in the turn to narrative. In D. J. Clandinin (Ed.), Handbook of narrative inquiry: Mapping a methodology (pp. 3-35). Thousand Oaks, CA: Sage.

Ranson, S. (2003). Public accountability in the age of neo-liberal governance. Journal of Education Policy, 18(5), 459-480.

Ranson, S. (2012). Schools and civil society: Corporate or community governance. Critical Studies in Education, 53(1), 29-45.

Ranson, S. (2018). Education, Democratic Participation: The Making of Learning Communities. London: Routledge.

Sahlberg, P. (2007). Education policies for raising student learning: The Finnish approach. Journal of Education Policy, 22(2), 147-171.

Sahlberg, P. (2010). Rethinking accountability in a knowledge society. Journal of Educational Change, 11(1), 45-61.

Sellar, S. (2015). Transparency and opacity: Levinasian reflections on accountability in Australian schooling. Educational Philosophy and Theory: Incorporating ACCESS, 47(2), 118-132. 
Stengers, I. (2010). Cosmopolitics 1. Minneapolis: University of Minnesota Press.

Stengers, I. (2011). Comparison as a matter of concern. Common Knowledge, 17(1), 48-63.

Tate, W. (2012). Research on schools, neighbourhoods, and communities. New York: Rowman \& Littlefield.

Vygotsky, L. S. (1997). Educational Psychology. Boco Raton, Fl: CRC Press.

Whatmore, S. J. (2009). Mapping knowledge controversies: Science, democracy and the redistribution of expertise. Progress in Human Geography, 33(5), 587-598.

Whatmore, S. J., \& Landström, C. (2011). Flood apprentices: An exercise in making things public. Economy and Society, 40(4), 582-610. 